\title{
Self-Images on YouTube
}

\begin{abstract}
This chapter discusses how unions have carried out revitalization processes by using YouTube videos to change their self-images. Here, we analyse the self-images of six different trade unions representing different social classes using two dimensions: the degree to which the trade union presents itself as an inclusive or exclusive organization and the degree to which the union expresses the values of collectivism or individualism. Exclusive collectivism, which has historically been crucial for union formation, remains relevant for working-class unions and upper-middle-class unions. However, inclusive individualism has become an increasingly important feature of white-collar workers' unions.
\end{abstract}

Keywords Self-image - Collectivism • Individualism • Inclusive organization · Exclusive organization

While YouTube provides unions with good opportunities to recruit new members or convey political campaigns, it is also a sphere in which images of the unions are produced and reproduced. When the second largest trade union in Sweden, the Municipal Workers' Union, transformed its chairperson Annelie Nordström into a man as the answer to the question 'How to get a raise in 47 seconds', the union was not only drawing attention to the issue of equal remuneration; it also created an image of itself as a feminist organization (Kommunal 2014,

(C) The Author(s) 2019

J. Jansson and K. Uba, Trade Unions on YouTube, https://doi.org/10.1007/978-3-030-24914-4_4 
March 5). The video clearly stated that women's lower life earnings are the result of their gender and nothing else. A feminist identity is not new for this union, as the female-dominated Municipal Workers' Union has not only fought for women's life earnings, but also battled other, male-dominated, unions (Arvidsson and Wettergren 1997; Nordström 2018; Waldemarson 2010). Fighting against gender inequality has become an integral part of this union; thus, it is important for this union to demonstrate this identity via social media.

Displaying a specific self-image is an important part of an organization's communication strategy and is particularly important for social movements, both internally and externally. Organizational images often-and especially in this context-reflect how the organizational elites choose to present the organization; that is, it is a projected image (see Gioia et al. 2000). Image management is crucial for member recruitment because organizational images trigger identification processes, and identity is often the very reason people choose to participate in movements (Snow and McAdam 2000). Building on social movement research, Kelly (1998) suggests in his union mobilization framework that identity is a crucial ingredient in successful mobilization. Identities are dynamic, however, and need to be constantly redefined and renegotiated as changes occur, and research indicates that unions have not been successful at adapting. One part of the union crisis is unions' incapability to adjust their self-image to changes in employment relations and the composition of the labour force (Lévesque et al. 2005; Moore 2011), triggering a vicious cycle: unions, then, are perceived as less relevant, leading to diminishing membership numbers. Losing many members, in turn, indicates low status for an organization. No one wants to be a member of a group or organization that has a low status or that does not align with one's identity. In such situations, members and organizational elites are likely to invest in changing an organization's image (Klandermans and de Weerd 2000), making it fruitful to examine self-images in the context of union online revitalization.

Thus, image management is an important issue for trade unions but not a new phenomenon. Unions, like most organizations, have always employed forms of image management (see for instance Jansson 2012; Manning 1998; Seaton 1982). Image management requires a movement or organization to have a clear vision of its own identity, along with insight into who it wants to attract and recruit. According to the literature on union revitalization, trade unions should try to attract new groups. 
In order to catch the attention of these groups, changing the image of the union seems to be necessary.

However, such active image management might be a double-edged sword: although image management might allow a union to add new elements to its image in order to attract new groups, the same process may result in a loss of its old identity and thereby alienate existing members. According to organizational theory, organizational identity is commonly defined as the mutual understanding of what is central, distinctive and endurable in an organization (Albert and Whetten 1985). Thus, organizational identity theory implies that the self-image emerges in the interaction between the members and the leaders. If one of these components changes, the self-image will also change. For example, if a male-dominated union suddenly recruits a large number of women, the union will hardly be able to describe itself as a 'male' organization anymore. New members that hold somewhat different ideas of what the organization is will change the organization from within; such processes can be considered to be 'natural' changes in self-image. If a union's membership composition changes very quickly, or if the organizational leaders try to strategically influence identity formation through image management (e.g. by focusing on certain groups or stressing certain properties or values), then internal conflict can result. Toocomprehensive changes might result in old members not 'recognizing' the organization anymore and, in the worst case, choosing to leave the union.

Image management is thus a delicate yet important matter for movements. Revitalization policies hold the potential to change the trade union movement profoundly, for better or for worse. In the digitalized age, social media is an important arena for image management, and YouTube is especially suitable for organization branding. Therefore, this final empirical chapter is devoted to how unions display their self-images on YouTube, as seen from a revitalization perspective.

\subsection{Self-Images: A Theoretical Framework}

Analysing the self-images of Swedish trade unions in their YouTube videos requires a definition of the concept of 'self-image', as well as a theoretical framework for interpreting the empirical findings. The theoretical and methodological literature on identity and self-image in movements is comprehensive (for identity and trade unions see, e.g., Hodder and 
Edwards 2015; Hyman 2001; Kelly 1998; Moore 2011). Building on organizational theory (Albert et al. 2000; Albert and Whetten 1985; Jansson 2012), we consider a 'self-image' to consist of three crucial components: (1) how a union talks about and describes itself, (2) how a union talks about and describes its members and (3) how a union talks about and describes others.

The first component of an organization's self-image, its description of itself, includes the properties the union ascribes to itself, the values the union defends and the actions it demonstrates as being appropriate for itself and its members. Its identity claim-that is, who or what the union claims to be-is an important and straightforward part of a union's description of itself. The second component, descriptions of the organization's members (and potential members), is also part of the organization's image because 'organizations often seek to generalize identification with an individual to identification with the organization through the routinization of charisma' (Ashforth and Mael 1989, p. 22). When a person identifies with another individual, it often implies that the person wishes 'to be like' that individual and thus to adopt the qualities of the other. Ashforth and Mael have applied this mechanism to organizations and have claimed that charismatic leadership works in the same way, as does the construction of the 'ideal member'. The image of an ideal member can attract the attention of members and potential members: if the organization frames its members as 'bold and courageous', this member image will impact the organization image. The third component of an organization's self-image is based on what the organization is not. According to social identity theory, self-perception and selfdefinition are constructed by what researchers call 'social identities'. In simple terms, people classify themselves and others in their environment in terms of various categories (Tajfel 1981, pp. 31, 45-49). Social identities are a person's perceived group affiliations - that is, 'the perception of oneness with or belongingness to some human aggregate' (Ashforth and Mael 1989, p. 21). Individuals always have a range of group affiliations, such as gender, parenthood or being a member of an association. Following the constant classification of 'we' versus 'others', our concept of what and who the 'others' are becomes a mirror of our self. Therefore, in order to capture unions' self-images, it is important to include how the unions talk about 'others'.

Together, these three elements-descriptions of the self, of the member and of 'others'-form the self-image of an organization and 
constitute the focus of our analysis. These three components can be detected not only through the spoken word, but also through visual details such as logos, photos, colours and the characters of the actors shown in the videos (Corrigall-Brown and Wilkes 2011; Doerr et al. 2013). Visual images are not a new tool for unions to use in their image management; film and photos have been frequently used by the labour movement throughout its history (Hardt and Ohrn 1981). Thus, we focused on these elements in our analysis of the videos.

\subsection{Revitalization Dimensions of Self-Images}

Establishing what the unions' self-images are and where they can be found in the material is insufficient to place the self-images in the context of revitalization; we need a framework for interpreting the self-images that are displayed in the unions' videos. What types of self-image, then, would we expect unions to display in an era of revitalization? We suggest that there are two particularly important dimensions in this context: the degree to which the trade union presents itself as an inclusive or exclusive organization and the degree to which the union expresses the values of collectivism or individualism.

With the first dimension, we aim to capture the complex issue of who belongs to the 'we' and who belongs to the 'others'. On the one hand, stressing specific traits and distinctiveness such as professional, occupational or class identity can be very effective for organizing, since it allows the unions to make use of already established identities. This is what most unions have traditionally done, and it implicates a certain exclusiveness - that is, not everyone can be a member of any union because union members share certain specific characteristic traits, such as profession. This organizational structure was challenged by the syndicalist movement, which emphasized that one union can organize everyone, and that the only 'other' that exists is the employer. This inclusive organizational principle has lately gained support and not only in a rhetorical sense. Research on union amalgamation as a revitalization strategy has reported that bigger unions have been created as a response to the union crisis (Gumbrell-McCormick and Hyman 2014). In this case, however, we are not examining whether or not the unions have broadened their membership composition; rather, we wish to know whether they are displaying an image that represents a broad set of employees. When a union presents itself as an inclusive organization, which implies a 'catch-all' 
strategy (cf. Kirchheimer 1966 in political party research), it opens the union's potential membership pool to encompass a broad range of people and occupations. Such an image, which implies that anyone can become a member, could appeal to new, previously unorganized, groups and could ultimately be a way of recruiting members.

With the second dimension, we seek to capture the elements of collectivism and individualism in the material. It may seem redundant to have such a category, as unions are social movements and ought to advocate collectivism; however, this is in fact an important aspect that addresses an old scholarly debate on why people join unions. It has been claimed that union membership is the result of strategic calculation of personal gain. In his famous book The Logic of Collective Action, Mancur Olson (1965) claimed that the only reasons for anyone to join any organization would be selfish reasons and that so-called selective incentives drive mobilization. Research suggests that in the absence of ideological traditions, post-industrial activists - and especially activists belonging to the middle class-engage in 'personalized politics' (Lichterman 1996). For such activists, individual expression rather than collective belonging becomes the driving force for activism. An organization that adopts such policies will display an image as a facilitator of self-fulfilment. The assumption that actors calculate the usefulness of each and every decision they make, and that self-fulfilment is their primary driving force, stands in a sharp contrast to identity research. Scholars within the latter field claim that selective incentives are far from being the only reason why individuals become members of associations or movements. Identification with the cause of a movement is equally important, if not more important, when joining a movement (Kelly 1998). In the context of revitalization, the notion of 'the collective' may be eroded as a result of a union reaching out to and recruiting new groups. Without a clear sense of 'what the organization is' and given the mission of capturing the politically volatile middle class, selective incentives may offer a way forward.

Thus, the second analytical dimension focuses on the unions' views on collectivism and individualism by analysing how the union talks about itself and its members in the videos: What is the role of the member in the organization and is a sense of 'we' present in the videos? Following social identity theory, we suggest that some unions emphasizing collectivistic values will present themselves as a strong 'we' and will present their members as part of the collective or movement. We call this 


\section{Inclusiveness Exclusiveness}

\begin{tabular}{lll}
\hline Collectivism & $\begin{array}{l}\text { Inclusive } \\
\text { collectivism }\end{array}$ & $\begin{array}{l}\text { Exclusive } \\
\text { collectivism }\end{array}$ \\
Individualism & $\begin{array}{l}\text { Inclusive } \\
\text { individualism }\end{array}$ & $\begin{array}{l}\text { Exclusive } \\
\text { individualism }\end{array}$
\end{tabular}

Fig. 4.1 Analytical framework of types of self-image

category 'collectivism'. Following the Olsian analysis, we suggest that other unions will instead emphasize individualistic values and will focus on the individual gains members receive from membership, while downplaying the idea that members are part of a movement. We call this category 'individualism'.

Combining the two dimensions results in four (ideal) types of self-image, which are displayed in Fig. 4.1. Trade unions have traditionally been characterized by exclusive collectivism: a strong collective with pronounced boundaries (often based on occupation) separating those who belong to the union from those who do not. Inclusive collectivism has traditionally been represented by the syndicalist movement: a strong collective at the centre of the movement, yet a movement that is open to anyone. Unions practising inclusive individualism have a catch-all strategy: a union that is open to anyone, but that stresses selective incentives for people to join rather than emphasizing a collective struggle. Such a member-organization contract becomes more of a transaction of services than a movement and has been described as 'the insurance company model' (Pettersson and Jansson 2013). Finally, exclusive individualism presents boundaries for the 'in group' and the 'out group': the union constitutes a unique entity for a particular group, but does so by emphasizing individualistic values and gains rather than collective struggle- that is, the union becomes a channel for self-expression.

We expect all these categories to be present in the videos uploaded on YouTube by Swedish unions, and we expect the class position of the union to influence the type of self-image that is displayed. 


\subsection{Selection of Cases}

The rapid loss of members after the 2006-2007 reforms by the centre-right government created a new situation for Swedish unions. The LO- and TCO-affiliated unions had already been incrementally losing members; however, these membership losses rapidly increased after 2006. Swedish unions have historically depicted themselves as 'growing' and 'successful', even as late as the 1980s (Jansson 2012, 2016); yet declining membership numbers do not align well with such a self-image. Thus, it is reasonable to assume that this crisis challenged the identity of the union movement and called for changes in how the unions presented themselves.

In the previous chapters, we compared all unions based on the three different trade union confederations. This qualitative analysis of unions' self-images in their YouTube videos requires a smaller sample, however. In order to obtain a comprehensive picture of different identity constructions, we focused on six different unions: two LO affiliates, two TCO affiliates and two Saco affiliates (Table 4.1). We chose to examine large unions; furthermore, for each confederation, we chose one union organizing employees in the private export-oriented sector and one union organizing employees in the sheltered public sector. Thus, we cover both male-dominated unions (i.e. the private industrial sector) and female-dominated unions (i.e. the public sector).

For the LO-affiliated unions in our analysis, we chose IF Metall and the Municipal Workers' Union (Kommunal). These are the two biggest unions in the LO; together, they constitute approximately $60 \%$ of the LO members (Medlingsinstitutet 2018, p. 222). Both have lost a considerable number of members in the past decades; however, the

Table 4.1 Unions selected for the self-image analysis

\begin{tabular}{lll}
\hline & Public sector & Private sector \\
\hline \multirow{2}{*}{ LO } & Municipal workers' union & IF Metal \\
& $(507,487$ members $)$ & $(247,140$ members $)$ \\
TCO & Vision & Unionen \\
& $(137,082$ members $)$ & $(538,845$ members $)$ \\
Saco & Akademikerförbundet SSR & Sweden's Engineers \\
& $(54,963$ members $)$ & $(122,453$ members $)$ \\
\hline
\end{tabular}

Sources Medlingsinstitutet (2018, pp. 222-223), membership numbers as of 31 December 2017 


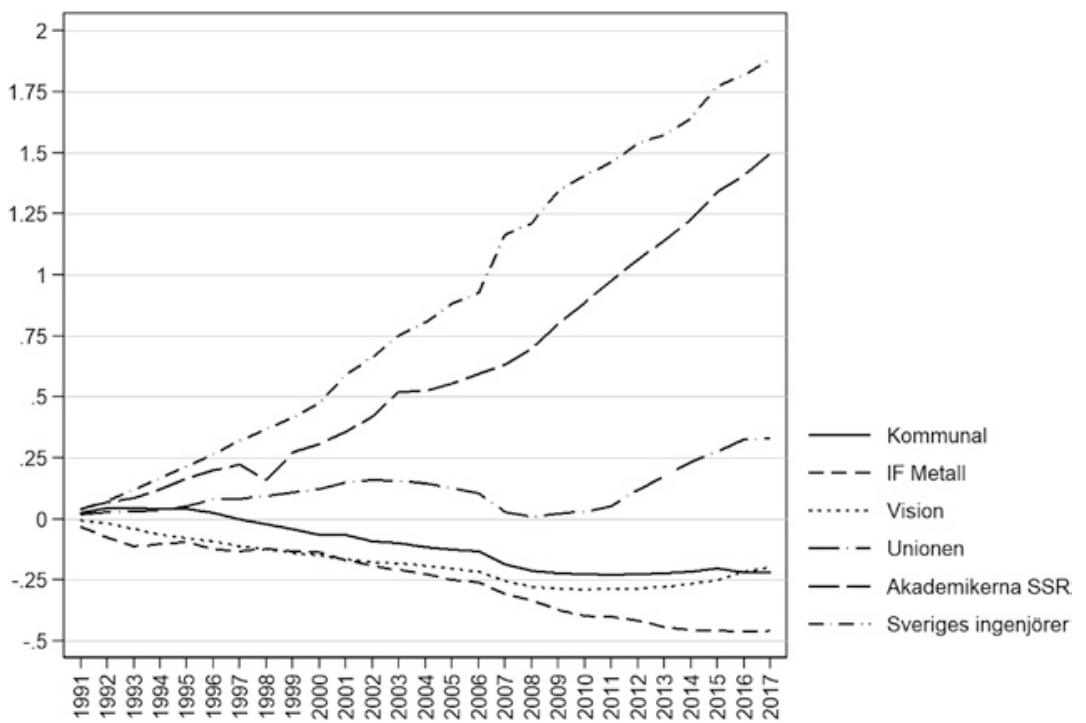

Fig. 4.2 Proportion of change in membership as of 2017, in comparison with 1990 (Source Kjellberg [2017], authors' calculations of changed membership)

Municipal Workers' Union, in contrast to IF Metall, managed to stop the trend and grew for a few years (see Fig. 4.2). The loss in members for IF Metall is not only due to the 2006-2007 reforms; structural changes in the economy have also caused the decline, as the industrial sector has shrunk since the 1990s. According to IF Metall, union density in the metal industry is still 77\% (IF Metall 2018, p. 13), in comparison with the national union density of $69 \%$. The Municipal Workers' Union was Sweden's largest union for decades, but was surpassed by Unionen in 2014. Traditional bonds to the Social Democratic Party have been preserved in both the Municipal Workers' Union and IF Metall; in fact, the present party leader of the Social Democratic Party is the former chairperson of IF Metall.

For the TCO-affiliated unions in our analysis, we again chose two large unions: Unionen and Vision. Both unions organize a broad set of occupations: Unionen organizes mainly white-collar workers in the private sector, while Vision organizes white-collar workers in the 
municipalities and regions (i.e. the public sector). Unionen was founded in 2008 through an amalgamation of the Swedish Union of Commercial Salaried Employees (HTF) and the Swedish Union of Clerical and Technical Employees in Industry (Sif). In 2014, the Union of Pharmacy Employees joined Unionen, making it the biggest union in Sweden. Unionen is the only trade union in our sample with a close gender balance among its members (approx. 56\% men and 44\% women). There are several similarities between the two white-collar unions in our sample. Both Unionen and Vision have lost members since 1990 (see Fig. 4.2) and both underwent thorough renewal processes as a result of their membership losses after 2006. They became the first unions to abandon their traditional informative union names (until then, union names had always contained information about who their members were). By changing names, these unions opened themselves to a broader membership. Unionen has managed to reverse the trend of membership decline, while Vision has stopped its decline. Within Vision, awareness of the need for image management was clear: the chairperson of Vision actually described the old organization as 'grey, old-mannish and outof-date' and as therefore needing a remake, including a name change (Jansson 2019).

For the Saco-affiliated unions in our analysis, we chose the Swedish Association of Graduate Engineers (referred to herein as the Engineers) and the Union for Professionals (i.e. the Akademikerförbundet SSR). The Engineers, which is the biggest Saco-affiliated union, belongs to the private sector, whereas the Akademikerförbundet SSR organizes professional employees in social services and thus belongs to the public sector. The Engineers was founded in 2007 through an amalgamation of the Swedish Society of College Engineers and the Association of Civil Engineers. Both Saco-affiliated unions have grown steadily over time (Fig. 4.2), a shift that is connected to structural changes in the economy as more people obtain university degrees. It was very difficult to find statistics on union density for each union in our sample; however, the Engineers estimated themselves to have a union density of $60 \%$ in 2008 (Hallstedt 2008, September 9), which is lower than the average union density in Sweden. Thus, the Engineers still have reason to engage in recruiting new members. 
For each of the six unions in our sample, we chose approximately ten videos for an in-depth analysis ${ }^{1}$ (see Appendix). Most of the videos posted by each union were found to be very similar; thus, after analysing about five of a union's videos, we did not find much new content in the subsequent five. Therefore, we assumed that ten videos were enough for the analysis.

\subsection{Exclusive Collectivism: The LO Unions}

The mobilization of the working class in unions in Sweden and beyond has been built on a strong sense of collectivism. This in turn has been rooted in a strong value-based identity, which lingers on in the unions today, albeit with some modifications.

The clearest example of a strong 'we' was found in IF Metall's videos. The union talks about itself as 'we as workers' (IF Metall 2014, September 3), 'we in the union' (IF Metall 2013, October 4) and 'we as an organization' (IF Metall 2014, December 22). For IF Metall, the whole notion of trade unions is built on the idea of a collective; by joining the union, each individual member will be strengthened by the collective (IF Metall 2013, October 4). To illustrate the empowering force of the collective, the union organized a demonstration in 2010, in which members from the local section worked together to turn a car upsidedown in six cities across Sweden. These events were filmed and posted on YouTube under the name 'The members in [city name] turn a car upside-down' (IF Metall 2010a, November 20; 2010b, November 20). The slogan of this campaign — 'together we are strong'—was intended to highlight the work performed by safety representatives in workplaces (Larsson 2010, November 20). Of course, the videos did not only demonstrate that ordinary people can lift heavy objects if they cooperate; it was also important that the objects being overturned in this case were cars-a primary product of the metal industry.

The word 'we' in the videos of IF Metall refers to either 'the union' or 'the workers'. The union is an organization that fights for

\footnotetext{
${ }^{1}$ Some of these videos are no longer available online. The owner of the YouTube account can always remove content as desired, and in our case, the Municipal Workers' Union has removed the majority of the videos used in this study, making them no longer available online (although some have been preserved in the e-archive DigiFacket).
} 
its members' rights to a safe and sustainable work environment, higher wages and spare time (IF Metall 2013, October 4; 2014, December 5). The union supports the member (IF Metall 2013, August 28), but ultimately consists of its members; thus, the union will be what the members want it to be (IF Metall 2014, December 22; 2017, May 21), leading to a strong emphasis on the collective. The usage of the concept of the 'worker' is another characteristic trait of IF Metall's self-image. Using the word 'worker' clearly connects the union and its members to a particular class position, of the unions in our sample, IF Metall was the only one to do this. Since it organizes workers in the industrial, metal and mining sectors, IF Metall consists of 'traditional workers'-a categorization that limits who 'we' are and excludes employees with other class positions and occupations from membership.

The Municipal Workers' Union, on the other hand, covers several different occupations, which could hamper the construction of a cohesive organizational identity; thus, class identity could offer a solution to this problem. However, the Municipal Workers' Union does not use the language of class when describing itself in its videos. Instead, like IF Metall, the Municipal Workers' Union displays a strong 'we', albeit using different social identities such as gender and member occupation. Many of the videos depict women performing different tasks in the welfare-state sector. A majority (approximately 78\%) of the members of the Municipal Workers' Union are women (Kjellberg 2017, pp. 125-126), which has affected the self-image of the union in many ways, not least as displayed by the video 'How to get a raise in 47 seconds' (Kommunal 2014, March 5). The Municipal Workers' Union also conducts campaigns related to what women do at work (Kommunal 2015, June 18) and has performed a number of actions addressing gender equality (e.g. Kommunal 2010, March 8; 2015, March 2). Many of the tasks performed by the Municipal Workers' Union's members involve heavy lifting, as they perform jobs such as assistant nurses or day-care workers. The physical strength demanded by the women in these occupations is emphasized in the videos. One of the videos begins with a woman asking: 'Can you manage an assistant nurse's work shift?' The video then shows a female assistant nurse performing normal work tasks simultaneously with a well-trained man lifting weights at a gym. The message is that while young men might go to the gym to work out, women working in care services get the same exercise by performing normal work tasks (Kommunal 2015, June 18). The video ends with the same 
question, and the text informs the viewer of an ongoing campaign in which all the tasks performed by an assistant nurse in one day have been converted into a physical test that anyone training at a gym can take. ${ }^{2}$

The occupational identities of the members are also used in the Municipal Workers' Union's videos to create a cohesive 'we'. The videos emphasize the importance of the work of the different occupational groups in the union. By performing welfare-state tasks in occupations such as assistant nurses, childcare workers, firefighters and bus drivers, the members are an indispensable part of society. Without people performing these tasks, the services provided by the state would stop functioning and turmoil would ensue (Kommunal 2014, August 27; 2017, January 30). The union repeatedly stresses that the members of these groups are 'heroes' (Kommunal 2014, August 27) that they perform the most important tasks in the world (Kommunal 2017, November 23) and that they struggle with both a physically and a psychologically difficult work environment (Kommunal 2015, June 18). Nevertheless, these groups perform tasks that tend to have a low status and low wages. Raising public awareness of what they do could also raise the status of the occupations and ultimately make a better case for increasing their wages. The image of the Municipal Workers' Union that is displayed in its videos bears the traits of 'exclusive collectivism': there is a clear 'we', but the union is not for everyone; it is for specific (struggling) groups.

Not only is there a clear 'we' among the LO-affiliated unions; there is also a distinguishable 'others'. 'Others' consist of the employers (IF Metall 2011, December 7; 2013, October 4; 2014, December 5), the centre-right government and the Sweden Democrats (IF-Metall 2014, September 3). Of course, 'employers' comprise the natural 'others' for unions; thus, by talking about employers as the opponent, and referring to an actor with interests opposite to those of the workers, a union emphasizes class. Employers are implicitly present in the videos of the Saco-affiliated union the Akademikerförbundet SSR, but are absent in the videos uploaded by the other unions. This does not mean that employers are not 'the other' for the rest of the unions in our sample; it only means that, for example, IF Metall choose to display such values.

In the LO unions' descriptions of 'others', exclusive collectivism is probably best characterized by the depictions of the struggle against

\footnotetext{
${ }^{2}$ http://klarapasset.nu/ (accessed 8 October 2018).
} 
the cutbacks and reforms adopted by the centre-right government in 2006-2014 (see, e.g., IF Metall 2012, September 10; 2012, September 14) and against the rising popularity of the Sweden Democrats. The Municipal Workers' Union uploaded an astonishing 242 videos with the title 'Therefore I want to change the government' before the 2010 parliamentary elections, and many of these videos referred to cutbacks and reforms targeting the Municipal Workers' Union's members. The rightwing populist party, the Sweden Democrats, also emerges as a significant 'other'. Using class analysis, IF Metall explains in the video titled 'It's about us' (Det handlar om oss) that the Sweden Democrats want to split up the working class along cultural lines; but ' (...) that would mean that the worker Kajsa would have more in common with the CEO Gustav than with her co-worker Samir. We do not believe that is true' (IF Metall 2014, September 3). The message is simple: all workers, regardless of cultural background or ethnicity, should join together in the struggle between labour and capital.

In summary, both of the LO-affiliated unions show similarities in regard to the self-images they display on YouTube: collectivism is strong, and both present a certain degree of exclusiveness; furthermore, there are clear boundaries around who belongs to the organization and who does not.

\subsection{Inclusive Individualism: The TCO Unions}

As the backbone of the middle class (Mills 1951), white-collar workers possess a central position as ' (...) those who are not particularly powerful, but who are not excluded from power; and who do not appear to exploit anyone in a particularly obvious way, but who do not seem to be exploited either' (Savage 1992, p. 1). As opposed to the working class, whose often-precarious position on the labour market has played a role in the construction of identity and the mobilization of organizations, white-collar workers have not shared 'lived experiences' that can be used to organize them into unions. Thus, from an international perspective, it has proven to be difficult to organize white-collar workers. This has not been the case in Sweden, however, where white-collar workers have been well-organized, especially from the 1970s onwards.

Both Vision and Unionen have produced a number of professional commercials with short messages explaining what services the unions could offer the viewer as a member. In general, however, very few of 
their videos contained information on the union per se, a description of what values the union stands for or an explanation of the main idea of a trade union membership.

Although Unionen produced a number of professional commercials with superheroes as the main characters (Unionen 2014, August 14; 2016, October 13;2017, October 20), these videos differed significantly from the Municipal Workers' Union's videos that used the concept of a 'hero'. Unionen's superhero theme, which was initiated in 2011 by a public relations firm (Anr bbdo) (Ström 2011, November 14), is visualized through people dressed $u p$ as superheroes. Thus, while the Municipal Workers' Union presents its members as heroes by showing people performing work-related tasks, Unionen does not focus on what its members do, possibly because Unionen organizes so many different occupations that work-related tasks cannot be used as an identity-building element. The slogan used in Unionen's commercials claims that the members 'get extraordinary powers' (kraft utöver det vanliga). The argument that joining together empowers employees is a well-known phrase used by the trade union movement. Paradoxically, however, even while using such a traditional mobilizing phrase, Unionen's videos do not contain references to the collective. When IF Metall used the same phrase and showed workers turning cars upside-down, the strength of the collective was clearly demonstrated. In contrast, Unionen's videos focus on the individual member and consistently inform the viewer about 'you as a member'.

A similar self-image is displayed in Vision's videos, in which a distinct focus on 'I' and 'you' emerges. Vision uses individuals as the point of departure in most of its videos. Focusing on individuals talking about their work-life experiences or their opinions on different issues, rather than having an official representative of the organization speak, diverts attention away from the collective. For example, in Vision's videos, individuals tell the viewer things such as, 'For me, a fair work life is to be seen for my skills and knowledge' (Vision 2015a, June 24); 'For me, a good work life is about a working dialog between employers and employees' (Vision 2015b, June 24); 'an unimportant issue for me, might be an important one for someone else' (Vision 2012b, October 1); and 'I have good communication with my boss; she has been able to tell me which tools I need to reach my goals' (Vision 2011, January 20). These videos raise important—and, for unions, relevant—questions through the perspectives of individual members. The point of departure, 
however, is exactly that: the perspectives of individual members. There is hardly any information on what the union defines as important issues or what the union's stance on such issues may be. More importantly, there is no clear definition of 'we', description of who a Vision member is or list of characteristics Vision members share. Nevertheless, Vision's videos contain notable visual indicators of identity: a majority of the people visible in the videos are women, and quite a few of them are young. Compared with the other unions in our sample, Vision's videos display pluralism by depicting people with different backgrounds and characteristics (i.e. ethnicity, gender, disabilities and age) (Vision 2012a, October 1). This is hardly a coincidence, as Vision stresses pluralism (Jansson 2016). The organization has set the goal of having 30\% of the entire organization's board members, at both central and local levels, be under 35 years of age (Vision 2015, p. 3). Vision does not argue whether the boards should mirror the membership composition-it simply views young people in unions as desirable. The background of Vision's policy was its aging membership; age quotas make it easier for younger people to advance as officials in the union (TCO-tidningen 2010). Thus, despite the lack of specific messages about gender and age, Vision's projected image in the videos is young and female.

Instead of arguing for better wages or gender equality, most of Unionen's commercials contain messages on the services the union can offer individual members (Unionen 2014, March 24; 2014, March 25). Unionen also stresses that membership helps employees who wish to develop 'a personal career' (Unionen 2014, March 24; 2014, August 14). In the video entitled 'That is why I am a member of Unionen', Unionen uses the same rhetorical method as Vision and focuses on individual members talking about why they joined the union. The reasons given include safety at work, insurance and career planning. One woman at the end of the video explains to the viewer: ' $(\ldots)$ and that the union wants me to become even more valuable to my employer; that is such a right way to think! That is why I am a member of Unionen' (Unionen 2014, March 24). A similar trend is visible in Vision's videos. For example, in a video entitled 'That's why you should be a member of Vision when you start to work' (Vision 2016, February 12), Vision lists a number of reasons why viewers should join the union, all of which refer to benefits for the individual, such as 'getting the best income insurance on the market'. The viewer is told that if you want to reach your dream job and invest in your career, Vision is the right union for you. There are few 
comments on what membership contains in terms of obligations towards the organization, what the union values are or who a Vision member is defined as. The same is true for Unionen. Instead, there seems to be an assumption that the potential members of Unionen and Vision are more interested in services and insurances than in joining a social movement. Unlike the Saco-affiliated unions (the Engineers and the Akademikerförbundet SSR), both of which stress who the member is and what the members have in common (i.e. being an engineer or working in the social services), Unionen and Vision make no references to shared values or characteristics. Unionen represents itself as an organization that serves its members with an impersonal member-union relationship: if the members pay the membership fees, they receive certain services. In fact, this image of a union is similar to that of an insurance company.

Individualism, in the form of self-expression and selective incentives, is a prominent feature in the self-image of these two TCO-affiliated unions. It should be noted here that Unionen does acknowledge the problems that are associated with being perceived as a kind of insurance company. In a video of a seminar arranged by Unionen, the vice chairperson discusses how the fact that its members expect services or other material gains in return for membership makes it difficult for the union to recruit officials and volunteers-so much so that in some cases, the union may need to pay members to perform union-related tasks (Unionen 2015, June 1).

Unlike the LO-affiliated unions and the Akademikerförbundet SSR, the videos of Vision and Unionen contain no references to 'others'. No mention is made of employers, other unions or politicians. By avoiding descriptions of values or ideology when describing the organization, Unionen and Vision are able to adopt an inclusive catch-all strategy for membership recruitment. A good example of Vision's inclusive selfimage is the campaign titled 'Everyone should receive the question', which started in 2012. Here, the question is: 'Do you want to become a member of Vision?' (Vision 2012a, October 1). Vision's message is that employees in Sweden are not actively against joining a union; in fact, most employees will join a union if they are asked to join. In other words, unions need to become better at approaching and reaching out to potential members. Like Unionen, Vision makes membership recruitment an important goal; in fact, Vision displays a counter on its webpage that shows how many new members have been recruited in the past month (Jansson 2016). Of course, making a video about its strategy of inviting 
as many people as possible to join the union would scarcely provide a good argument for why someone would join (for similar content, also see Vision 2016, December 15). Instead, Vision's videos inform its members about union work or demonstrate to other unions that Vision is very active in recruiting.

In attempting to organize almost anyone working as a white-collar worker in the private sector, as Unionen does, the union has been very aggressive in marketing itself. However, this kind of marketing challenges the old consensus of not 'stealing' other unions' members. Early in its development, the Swedish trade union movement adopted the principle of industrial unionism, meaning one union per workplace and thus only one collective agreement (Gråbacke 2002, pp. 17-19). When the white-collar workers and upper-middle classes eventually formed unions and gained collective bargaining rights, the praxis of 'one union per trade union confederation per work place' became the norm. These informal rules were aimed at preventing unions from competing over the same members. But with the new, inclusive, 'catch-all' strategy, which is employed by Unionen in particular, these old arrangements are challenged.

The self-images of the two TCO-affiliated unions are best described as 'inclusive individualism'. Although this type of self-image may be used for recruiting purposes, it is not clear whether this strategy is sustainable, or how the 'older' members will react to these changes in their unions. In future, the fact that there seems to be very little reason for members to identify with the organization may create a problem.

\subsection{Professions Above All? The Saco Unions}

The Saco-affiliated unions-the Engineers and the Akademikerförbundet SSR - constitute the last two organizations in our study. The Engineers' videos provide the most clear-cut example of 'exclusive collectivism' in our sample. Most of the videos uploaded by the Engineers centre on profession: as engineers, the union's members are told that they have a great deal to be proud of. This union's videos continually and effectively use history to highlight the importance of engineers; the viewer is constantly reminded that engineers have played a crucial role in human development and, through their inventions, have solved problems to make life easier for humans. Furthermore, engineers will continue to solve problems in the future (Sveriges ingenjörer 2012, January 20; 2015 , July $6 ; 2016$, January 16;2016, October 11). Glorification of the 
engineering profession and a strong belief in technological development characterize the videos. There is no critical discussion on the disadvantages of technical innovations (e.g. war, pollution or climate change). The engineer is presented as the brain behind all technical innovations, and technical innovations are framed as having made society into what it is today. The exclusiveness of this organization is very clear.

Thus, a strong 'we' emerges in the Engineers' videos that consists of those in the engineering profession. This constant referral to 'we, as engineers' emphasizes collectivism. The Engineers started as an association for people interested in technology, and then developed into a trade union for the engineering profession, thus blurring the line between professional association and trade union (Sveriges ingenjörer 2012, January 20).

Historicity is an important component in formulating an organizational identity (Jansson 2012; Steinmetz 1992), and the Engineers make good use of it to create its self-image. The profession is further emphasized through videos containing seminars or information on important engineering-related issues such as eye tracking (i.e. controlling your computer with your eyes) and artificial intelligence (Sveriges ingenjörer 2015 , November 10;2018, April 26). These videos also serve the union members by providing information about their profession that is likely to interest them. In the Engineers' videos, there is no uncertainty about what the organization is and who its members are.

The Akademikerförbundet SSR also talks about itself as a cohesive 'we', unlike Vision and Union, whose videos often talk about 'the member' (Akademikerförbundet SSR 2016, April 6). For the Akademikerförbundet SSR, as for the Engineers, the word 'we' is rooted in the profession-in this case, social worker (socialsekreterare). Most of this union's videos take this perspective as their point of departure (see, e.g., Akademikerförbundet SSR 2014, March 13; 2015, March 19; 2015, April 7; 2018, May 2). One video depicts the collective by discussing the union's history as one in which people have interacted in order to achieve goals; in one scene, two people help each other to lift an iron bar. In the same video, the union uses the word 'struggle' to describe its work (Akademikerförbundet SSR 2018, May 2). The organization has been growing and has thus been successful in its mission. But the videos uploaded by the Akademikerförbundet SSR depict a duality in its definition of 'we': the union and its members are not only social workers but also part of a larger movement-the trade union movement. One prominent example of the Akademikerförbundet SSR being 
depicted as an actor in the greater trade union movement is a video presenting a recent campaign to increase membership numbers in the union movement in general. In this video, the chairperson of the union, Heike Erkers, talks to Anders Ferbe, the former chairperson of IF Metall (Akademikerförbundet SSR 2018b, April 12). Erkers announces that the union has just appointed Ferbe to investigate ways to increase membership rates. 'What is important is that people join $a$ union, not which. Increasing union membership numbers in general is important to preserve the collective bargaining system in Sweden', Ferbe says. In the next frame, the viewer hears a crashing sound of glass breaking and the text 'without us, it all goes to hell' emerges.

This video presents a clear message about the aims and uses of unions while simultaneously saying something about how the Akademikerförbundet SSR positions itself in the trade union landscape. First, the union talks about 'we in the union movement', thus clearly defining the Akademikerförbundet SSR as a part of the larger labour movement. Even though the Akademikerförbundet SSR is exclusive in terms of who its members are (i.e. employees with a college degree working in the social services), defining itself as a part of a larger movement signals inclusiveness. Second, appointing Ferbe, who served as the chairperson of IF Metall for many years, signals cooperation beyond the boundaries of class and sector (Akademikerförbundet SSR 2018a, April 12). Third, the video implies that unorganized workers comprise a group that needs to be mobilized and thus constitute an 'other' to all trade unions.

While collectivism is strong in the videos posted by the Engineers, the union has also posted videos containing advice on labour law, work environmental issues and the forms of insurance that membership provides (Sveriges ingenjörer 2009, September 7; 2016, May 13; 2017, August 7; year unknown). Of course, videos on insurance and career advice can be considered to be selective incentives; however, unlike the descriptions of services in the TCO videos, these 'services' provided by the union are not presented as arguments for joining the union; rather, they are described in order to inform members of their existence.

In contrast to Vision and Unionen, the Akademikerförbundet SSR uses YouTube to spread political messages. The Akademikerförbundet SSR and Vision have partially overlapping membership cohorts: many of the members of the Akademikerförbundet SSR could just as well join Vision. Therefore, the differences between these unions are interesting. Many of the videos posted by the Akademikerförbundet SSR are openly 
critical of how politicians have mismanaged social insurance systems and suggest that when the unemployed or ill end up with social welfare assistance instead of receiving unemployment or health insurance, the welfare system will collapse (Akademikerförbundet SSR 2014, March 13; 2015, March 19; 2015, April 7). Under the hashtag \#lagavälfärden (fix the welfare state), the union started a campaign in 2014 that launched policy proposals on how to fix the welfare-state system (Akademikerförbundet SSR 2014, March 13). In this, the Akademikerförbundet SSR clearly aimed to impact politics in order to allocate more resources not only to the social welfare system (where most of its members work), but also to the other forms of social insurance (particularly unemployment insurance and health insurance), because when one type of insurance does not work properly, the other types also suffer. Left-leaning parties are usually the ones that advocate the allocation of more resources to the social insurances; thus, this issue is not politically neutral. In most of the videos, politicians are depicted as the 'others' the union wants to impact. Employers are mentioned as well, however. The Akademikerförbundet SSR describes the current situation in the social services as problematic: the welfare-state system will only work if there are individuals who want to perform the tasks. If the working conditions for employees deteriorate more than they have already done, it will be difficult to recruit employees in the future. This is presented as a well-known fact to employers and politicians; thus, the videos imply, employers and politicians should do something about the situation (Akademikerförbundet SSR 2015, March 19; 2016, April 6). The task of the union, according to its videos, is to negotiate wages and improve working conditions (Akademikerförbundet SSR 2016, April 6).

In summary, the two Saco-affiliated unions display clear self-images of organizations that are built on professions. Collectivism is very strong; however, even though both unions are exclusive in the sense that the membership cohort is clearly defined, the videos of the Akademikerförbundet SSR contain some degree of inclusiveness and cross-class cooperation.

\subsection{Conclusions}

Videos are a good means of presenting, promoting and displaying self-images. Swedish trade unions surely know this and use YouTube accordingly as an excellent medium for this purpose. A comparison 
of the self-images of the working-class, white-collar-worker and upper-middle-class unions revealed similarities and differences in how the unions have chosen to present themselves and their members. Collectivism is still strong in the working class and among the Sacoaffiliated unions, but with somewhat different points of departure: for IF Metall, class identity is still an important part of the union's self-image; for the Municipal Workers' Union, occupational identities and gender are used instead; and for upper-middle-class unions, the professions they represent are used to build their self-images. Professions and occupational identities are good grounds for mobilization in unions; these identities are disconnected from ideologies and political issues, yet are shared by members of that occupation or profession.

Perhaps the most interesting cases in our sample were those of the white-collar worker unions, in which inclusive individualism was strong. Selective incentives have become an important part of membership recruitment for these unions and appear to be a successful strategy, at least in terms of increasing the number of members. These results partly coincide with Hodder and Edward's claim that unions in the manufacturing industry use a more class-based approach while organizing, whereas white-collar unions have a market focus (Hodder and Edwards 2015). White-collar workers have had fewer common structural features to use in terms of creating self-images, and it is known that the middle class, is far more individualistic than the working class. Additionally, Sweden is a highly individualized country that scores very high on self-expression values (Ingelhart and Welzel 2005). Therefore, inclusive individualism is understandable and may even be a precondition for recruiting new members. Diminishing differences between the working class and white-collar workers, increased individualism among people's attitudes in general and the ambition to be a 'catch-all' union may be factors affecting these self-images. The question of what implications inclusive individualism has for the trade union movement and for its abilities to act as a collective actor in the long run remains to be answered.

\section{REFERENCES}

Akademikerförbundet SSR. (2014, March 13). Något blev väldigt fel. https://www.youtube.com/watch?v=I26uMrhQdfg. Accessed 17 Sept 2018. Akademikerförbundet SSR. (2015, March 19). Det hjälper inte att blunda. https://www.youtube.com/watch?v=EM7D_4VuSkI. Accessed 17 Sept 2018. 
Akademikerförbundet SSR. (2015, April 7). Shutsnackat. https://www.youtube. com/watch?v=83OOxWroL20. Accessed 17 Sept 2018.

Akademikerförbundet SSR. (2016, April 6). Knäck obälsan. https://www.youtube.com/watch?v=sTUHwcR5iT4. Accessed 17 Sept 2018.

Akademikerförbundet SSR. (2018a, April 12). Den svenska modellen hotas. https://www.youtube.com/watch?v=CWf7pvinx78. Accessed 17 Sept 2018.

Akademikerförbundet SSR. (2018b, April 12). Heike Erkers och Anders Ferbe. Utan oss gair det àt helvete. https://www.youtube.com/watch?v=hBK4tljXVVE. Accessed 17 Sept 2018.

Akademikerförbundet SSR. (2018, May 2). Akademikerförbundet SSR 1958-2018. https://www.youtube.com/watch?v=SxaNGTvtkUM. Accessed 17 Sept 2018.

Albert, S., Ashforth, B. E., \& Dutton, J. E. (2000). Organizational identity and identification: Charting new waters and building new bridges. Academy of Management Review, 25(1), 13-17.

Albert, S., \& Whetten, D. A. (1985). Organizational identity. Research in Organizational Behavior, 7, 263-295.

Arvidsson, L., \& Wettergren, G. (1997). När Lillemor fick makten. Stockholm: Rabén Prisma.

Ashforth, B. E., \& Mael, F. (1989). Social identity theory and the organization. The Academy of Management Review, 14(1), 20-39.

Corrigall-Brown, C., \& Wilkes, R. (2011). Picturing protest: The visual framing of collective action by First Nations in Canada. American Behavioral Scientist, $56(2), 223-243$.

Doerr, N., Mattoni, A., \& Teune, S. (2013). Advances in the Visual Analysis of Social Movements. Bingley: Emerald Group Publishing Limited.

Gioia, D. A., Schultz, M., \& Corley, K. G. (2000). Organizational identity, image, and adaptive instability. The Academy of Management Review, 25(1), 63-81.

Gråbacke, C. (2002). Möten med marknaden. Tre svenska fackförbunds ageranden under perioden 1945-1976, University Dissertation. Ekonomisk-historiska institutionen, Göteborg.

Gumbrell-McCormick, R., \& Hyman, R. (2014). Trade Unions in Western Europe: Hard Times, Hard Choices. Oxford: Oxford University Press.

Hallstedt, N. (2008, September 9). Sveriges ingenjörer går framåt. Kollega. Stockholm.

Hardt, H., \& Ohrn, K. B. (1981). The eyes of the proletariat: The worker-photography movement in Weimar Germany. Studies in Visual Communication, $7(3), 46-57$.

Hodder, A., \& Edwards, P. (2015). The essence of trade unions: Understanding identity, ideology and purpose. Work, Employment \& Society, 29(5), 843-854. 
Hyman, R. (2001). Understanding European Trade Unionism: Between Market, Class and Society. London: Sage.

IF Metall. (2010a, November 20). Medlemmarna $i$ Kiruna vänder en bil. https://www.youtube.com/watch?v=G019pDJ966I. Accessed 8 Oct 2018.

IF Metall. (2010b, November 20). Medlemmarna $i$ Trollhättan vänder en bil. https://www.youtube.com/watch?v=HLzfvTRRLto. Accessed 8 Oct 2018.

IF Metall. (2011, December 7). En vecka med avtalslöst tillstånd. https://www. youtube.com/watch?v=vMKnqa0Hajs. Accessed 8 Oct 2018.

IF Metall. (2012, September 10). Regeringens försämrade föräldraförsäkring, https://www.youtube.com/watch?v=mlQAXxRiDio. Accessed 8 Oct 2018.

IF Metall. (2012, September 14). Rättvis ersättning oavsett ålder. https://www.youtube.com/watch?v=7JT2cK_mMCo. Accessed 8 Oct 2018.

IF Metall. (2013, August 28). Kompetensbanken. https://www.youtube.com/ watch?v=O7BY_byIoJA. Accessed 8 Oct 2018.

IF Metall. (2013, October 4). Du är aldrig ensam $i$ IF Metall. https://www.youtube.com/watch?v=Ksx5t292Z1M. Accessed 8 Oct 2018.

IF Metall. (2014, September 3). Det handlar om oss. https://www.youtube. com/watch?v=dkYODExNxnM. Accessed 8 Oct 2018.

IF Metall. (2014, December 5). What If There Were No Trade Unions. https:// www.youtube.com/watch?v=2YaSPC7YhbI. Accessed 8 Oct 2018.

IF Metall. (2014, December 22). Julhälsning från Anders Ferbe. https://www.youtube.com/watch?v=lyGat0uJX2s. Accessed 8 Oct 2018.

IF Metall. (2017, May 21). Kongressavsnittet “Var organisation”. https://www. youtube.com/watch?v=gONKfxTwY4o. Accessed 8 Oct 2018.

IF Metall. (2018). Verksambetsberättelse 2017. Stockholm: IF-Metall.

Ingelhart, R., \& Welzel, C. (2005). Modernization, Cultural Change and Democracy. Cambridge: Cambridge University Press.

Jansson, J. (2012). Manufacturing Consensus: The Making of the Swedish Reformist Working Class. Uppsala: Acta Universitatis Upsaliensis.

Jansson, J. (2016). De visionära kommunaltjänstemännen: Självbilder hos ett fack i förändring. In B. Anders (Ed.), Tjänstemännen och deras rörelser: Fackligt arbete bland svenska tjänstemän ur ett hundraarigt perspektiv. TAMArkiv: Stockholm.

Jansson, J. (2019). Re-inventing the self: Implications of trade union revitalization [In review].

Kelly, J. E. (1998). Rethinking Industrial Relations: Mobilization, Collectivism and Long Waves. New York: Routledge.

Kirchheimer, O. (1966). The transformation of the Western European party systems. In J. LaPalombara \& M. Weiner (Eds.), Political Parties and Political Development (pp. 177-200). Princeton, NJ: Princeton University Press.

Kjellberg, A. (2017). The Membership Development of Swedish Trade Unions and Union Confederations Since the End of the Nineteenth Century. Lund: Department of Sociology, Lund University. 
Klandermans, B., \& de Weerd, M. (2000). Group identification and political protest. In S. Stryker, T. J. Owens, \& R. W. White (Eds.), Self, Identity and Social Movements (pp. 68-90). Minneapolis: University of Minnesota Press.

Kommunal. (2010, March 8). Internationella kvinnodagen 2010. Stockholm: DigiFacket-archive, ARAB.

Kommunal. (2014, March 5). How to get a raise in 47 seconds. https://www.youtube.com/watch?v=Y-bLUSF-Xtc. Accessed 26 June 2018.

Kommunal. (2014, August 27). Se filmen om välfärdens hjältar. Stockholm: DigiFacket-archive, ARAB.

Kommunal. (2015, March 2). \#alltid8mars, DigiFacket-archive, ARAB.

Kommunal. (2015, June 18). Klarar du en undersköterskas pass? Stockholm: DigiFacket-archive, ARAB.

Kommunal. (2017, January 30). Välfärdens yrkesproffs. Stockholm: DigiFacketarchive, ARAB.

Kommunal. (2017, November 23). Barnskötare - världens viktigaste jobb. Stockholm: DigiFacket-archive, ARAB.

Larsson, H. (2010, November 20). Ett lyft för facklig styrka. Dagens Arbete. Stockholm.

Lévesque, C., Murray, G., \& Queux, S. L. (2005). Union disaffection and social identity: Democracy as a source of union revitalization. Work and Occupations, 32(4), 400-422.

Lichterman, P. (1996). The Search for Political Community: American Activists and the Reinvention of Commitment. Cambridge: Cambridge University Press.

Manning, P. (1998). Spinning for Labour: Trade Unions and the New Media Environment. Aldershot: Ashgate.

Medlingsinstitutet. (2018). Avtalsrörelsens och lönebildningen 2017. Stockholm: Medlingsinstitutet.

Mills, C. W. (1951). White Collar: The American Middle Classes. New York: Oxford University Press.

Moore, S. (2011). New Trade Union Activism: Class Consciousness or Social Identity? Basingstoke: Palgrave Macmillan.

Nordström, A. (2018). Min trädgård är full av skärvor. Stockholm: Leopard förlag.

Olson, M. (1965). The Logic of Collective Action-Public Goods and the Theory of Groups. Cambridge, MA: Harvard University Press.

Pettersson, J., \& Jansson, J. (2013). Aktivist eller siffror? Stockholm: Tiden.

Savage, M. (1992). Property, Bureaucracy, and Culture: Middle Class Formation in Contemporary Britain. London: Routledge.

Seaton, J. (1982). Trade unions and the media. In B. Pimlott \& C. Cook (Eds.), Trade Unions in British Politics: The First 250 Years (pp. 272-290). London and New York: Longman. 
Snow, D. A., \& McAdam, D. (2000). Identity work processes in the context of social movements: Clarifying the identity/movement nexus. In S. Stryker, T. J. Owens, \& R. W. White (Eds.), Self, Identity, and Social Movements (pp. 41-67). Minneapolis: University of Minnesota Press.

Steinmetz, G. (1992). Reflections on the role of social narratives in working-class formation: Narrative theory in the social sciences. Social Science History, $16(3), 489-516$.

Ström, C. (2011, November 14). Unionen satsar på superhjältar. Resumé. Stockholm.

Sveriges ingenjörer. (2009, September 7). Inkomstförsäkring - Blivande chef med inkomstförsäkring. https://www.youtube.com/watch?v=KH5ggQTWTvg Accessed 17 Sept 2018.

Sveriges ingenjörer. (2012, January 20). Svensk ingenjörshistoria film 1 av 3. https://www.youtube.com/watch?v=hR2gd4Oq198\&t=2s. Accessed 17 Sept 2018.

Sveriges ingenjörer. (2015, July 6). Det här är idélandet Sverige. https://www. youtube.com/watch?v=q534lRI7gvE\&t=1s. Accessed 17 Sept 2018.

Sveriges ingenjörer. (2015, November 10). Ögonstyrning av datorer - Mårten Skogö, Tobii Eyetracker. https://www.youtube.com/watch?v=MtnKsEzUE7E\&t=469s. Accessed 18 Sept 2018.

Sveriges ingenjörer. (2016, January 16). Visar vikten av ingenjörskunskap. https:// www.youtube.com/watch?v=LQD13LcXSKY. Accessed 17 Sept 2018.

Sveriges ingenjörer. (2016, May 13). Flexpension för din grundtrygghet. https://www.youtube.com/watch?v=uICyjmX3jo0. Accessed 17 Sept 2018.

Sveriges ingenjörer. (2016, October 11). Sveriges Ingenjörer-While Our Members Develop Sweden We Develop Them. https://www.youtube.com/ watch?v=vVx6yQBGsWg\&t=31s. Accessed 18 Sept 2018.

Sveriges ingenjörer. (2017, August 7). Nybeter i teknikavtalet 2017-2020. https:// www.youtube.com/watch?v=9d98s59mavI\&t=1s. Accessed 17 Sept 2018.

Sveriges ingenjörer. (2018, April 26). Höjdpunkter från seminariet "AI - bara av godo?” https://www.youtube.com/watch?v=CvfHvq2xnvQ. Accessed 18 Sept 2018.

Sveriges ingenjörer. (Year unknown). Work Without Limits. Accessed 27 July 2018.

Tajfel, H. (1981). Human Groups and Social Categories: Studies in Social Psychology. Cambridge: Cambridge University Press.

TCO-tidningen. (2010). SKTF röjer väg för radikal föryngring inom förbundet. Stockholm: TCO-tidningen.

Unionen. (2014, March 24). Därför är jag medlem $i$ Unionen. https://www. youtube.com/watch?v=kCvJEDh5tZ0. Accessed 18 Sept 2018.

Unionen. (2014, March 25). Vilka försäkringar ingår i jobbet. https://www.youtube.com/watch?v=WwqKwT0ailg. Accessed 19 Sept 2018. 
Unionen. (2014, August 14). Kan du också bli medlem $i$ Unionen?, https://www. youtube.com/watch?v=pR0yo69EO3U. Accessed Sept 182018.

Unionen. (2015, June 1). Unionens trendseminarier: Organisationer och föreningar 20150525 del 1. https://www.youtube.com/watch?v=lxKQNRXl3Vc. Accessed 18 Sept 2018.

Unionen. (2016, October 13). Unionen - Framfötterna $\Upsilon T$. https://www.youtube.com/watch?v=g2Cdh1RtSKs. Accessed 18 Sept 2018.

Unionen. (2017, October 20). Unionen kaffe fail. https://www.youtube.com/ watch?v=xpvfmi97IEU. Accessed 18 Sept 2018.

Vision. (2011, January 20). Utvecklingssamtalet. https://www.youtube.com/ watch?v=KVx_26PtyxA. Accessed 9 Oct 2018.

Vision. (2012a, October 1). Alla ska få frågan. https://www.youtube.com/ watch?v=xAF191F_9Kg. Accessed 19 Sept 2018.

Vision. (2012b, October 1). Avtalsrörelse 2012 - Gladare mandagar. https:// www.youtube.com $/$ watch?v=BTlz_f2URlw\&t=35s. Accessed 9 Oct 2018 .

Vision. (2015). Skyddsombud. Stockholm: www.vision.se.

Vision. (2015a, June 24). Ett \#schystarbetsliv, del 1, https://www.youtube.com/ watch?v=LPb7mzUj3ag. Accessed 9 Oct 2018.

Vision. (2015b, June 24). Ett \#schystarbetsliv, del 2. https://www.youtube.com/ watch?v=XmMIZ9s92Gs. Accessed 9 Oct 2018.

Vision. (2016, February 12). Därför ska du vara med $i$ Vision när du börjar jobba. https://www.youtube.com/watch?v=xAF191F_9Kg. Accessed 19 Sept 2018.

Vision. (2016, December 15). Medlemstipset. https://www.youtube.com/ watch?v=c7Yzr7KHMDc. Accessed 9 Oct 2018.

Waldemarson, Y. (2010). Mellan individ och kollektiv: Kommunal 1960-2010. Stockholm: Premiss. 
Open Access This chapter is licensed under the terms of the Creative Commons Attribution 4.0 International License (http://creativecommons.org/licenses/ by $/ 4.0 /)$, which permits use, sharing, adaptation, distribution and reproduction in any medium or format, as long as you give appropriate credit to the original author(s) and the source, provide a link to the Creative Commons license and indicate if changes were made.

The images or other third party material in this chapter are included in the chapter's Creative Commons license, unless indicated otherwise in a credit line to the material. If material is not included in the chapter's Creative Commons license and your intended use is not permitted by statutory regulation or exceeds the permitted use, you will need to obtain permission directly from the copyright holder.

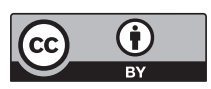

